\begin{tabular}{|ccc|}
\hline & ANNALES INSTITUTI SLAVICI \\
& UnIVERSITATIS DEBRECENIENSIS & \\
SLAVICA XLIX & 2020 & DEBRECEN \\
\hline
\end{tabular}

АНдрей НАРУШЕВИЧ

\title{
ЗНАЧЕНИЕ ОДУШЕВЛЕННОСТИ - НЕОДУШЕВЛЕННОСТИ ИМЕНИ СУЩЕСТВИТЕЛЬНОГО И КОНТЕКСТ
}

\section{The Importance of Animacy-Inanimacy Category of the Noun and the Context}

\begin{abstract}
The article considers the semantic aspect of the of animacy-inanimacy category in nouns in Russian language, in particular, peculiarities of collocability of some nouns with verbs in terms of animacy-inanimacy category. The study of the semantic interaction of nouns and animate-inanimate marked verbs, which are collocating with these nouns, allows to detect combination of signs of "animate" or "inanimate" in meanings of some nouns with fluctuant grammatical indicator of animacy-inanimacy category. Thus, this study can raise the issues about the cognitive factor in meaning formation process and also about specific character of the process how peculiarities of cognitive experience, received from human exploration of the environment, are expressed.
\end{abstract}

Keywords: the category of animacy, semantics, compatibility

\section{Введение}

Категория одушевленности-неодушевленности имен существительных русского языка неоднократно подвергалась исследованию в работах различных ученых. В целом реконструирован процесс формирования данной категории, изучено функционирование категории одушевленности-неодушевленности в современном русском языке [МАДОяН 1980, КРЫСЬКО 1994, ШАКАР 2018, НАРУШЕВИч 2002 и др.]. Рассмотрены аналогичные категории в родственных белорусском и украинском языках [КУзЬМЕНКОВА 1980, МОРОЗ 2007, КОЗІНА 2012] Однако до настоящего времени в лингвистической науке не было осуществлено системное описание одушевленности-неодушевленности, интегрирующее разноуровневые средства выражения значения одушевленностинеодушевленности. По этой причине вопрос о связи семантики имени существительного и грамматических средств выражения одушевленности-неодушевленности остается открытым.

\section{Постановка проблемы}

В лингвистической литературе недостаточное внимание уделяется изучению переходных языковых явлений, связанных с одушевленностью-неодушевленностью, отсутствует описание значений имен существительных, совмещающих семы, указывающие на живое и неживое. Недостаточно изучены признаковые слова (глаголы и имена прилагательные), способные указывать 
на значение одушевленности- неодушевленности имени существительного. Не был осуществлен анализ сочетаемости имен существительных с другими языковыми единицами в аспекте одушевленности-неодушевленности.

Исследование значения одушевленности-неодушевленности не может быть ограничено рассмотрением изолированных имен существительных, поскольку уже тот факт, что грамматическим показателем категории одушевленности-неодушевленности является конкретная форма винительного падежа, предполагает функционирование слова в составе некоторой конструкции, в составе определенного контекста.

\section{Материал и метод исследования}

Материалом для языкового анализа в данной работе послужил корпус примеров, сформированный автором на основе сплошной выборки из художественных и публицистических произведений.

Использование метода компонентного анализа позволяет выделить среди имен существительных ряд лексико-семантических групп, члены которых объединены общим (базовым) семантическим компонентом.

Выделенные группы характеризуются специфическими различиями в структуре значения одушевленности-неодушевленности составляющих их элементов. Имена существительные, четко противопоставленные по одушевленности-неодушевленности, составили две основные группы:

1) «абсолютно-одушевленные» - объединены общим семантическим компонентом «живое существо»;

2) «абсолютно-неодушевленные» - объединены общей семой «неживой предмет».

Анализ семантики одушевленности-неодушевленности позволяет также выделить слова, совмещающие в своих значениях семы, отражающие признаки живого и неживого. Эти имена существительные составили ряд лексикосемантических групп, получивших название промежуточных (занимающих промежуточное положение между группами «абсолютно-одушевленных» и «абсолютно-неодушевленных» существительных):

1. имена существительные, обозначающие умерших людей;

2. имена существительные, обозначающие человека и животных на стадии эмбрионального развития;

3. имена существительные, обозначающие микроорганизмы;

4. имена существительные, обозначающие животных в качестве пищи;

5. имена существительные, обозначающие персонажи мифов, легенд, сказок и фантастических произведений;

6. имена существительные, обозначающие кукол;

7. имена существительные, обозначающие игровые фигуры;

8. имена существительные, обозначающие совокупности живых существ;

9. имена существительные, обозначающие растения. 


\section{Результаты}

Как показывают наши наблюдения, сема «живое» («неживое») может проявляться не только в значениях имен существительных, но и в значениях признаковых слов. Действительно, анализ показал, что в языке сему одушевленностинеодушевленности имеют глаголы и имена прилагательные. Это проявляется в том, что глаголы и прилагательные могут обозначать признаки предметов, характеризующие данные предметы как живые или неживые. К примеру, значение глагола читать указывает на то, что действие совершается лицом (человеком) и направлено на неживой предмет: читать книгу, газету, объявление и m. $n$.

Глаголы, способные указывать на одушевленность (неодушевленность) имен существительных, мы будем называть одушевленно (неодушевленно)маркированными.

Семантика одушевленности-неодушевленности имени существительного может быть рассмотрена в ее взаимосвязи с контекстом - элементами речевой цепи, несущими информацию об актуализации конкретного значения слова.

Как известно, связь языковых единиц в составе высказывания определяется законом семантического согласования, то есть необходимого повторения одних и тех же сем в сочетающихся единицах. Повторяющуюся сему, выполняющую связующую функцию, называют классемой или синтагмемой. Сходное понимание семантического согласования находим в работе Ю.С. Степанова, выдвигающего понятие «длинного семантического компонента» - общего семантического признака имен и предиката одного предложения [СТЕПАНОВ 1981: 357].

В.Г. Гак описывает три наиболее общих типа взаимодействия слова и его семантического окружения:

1) семантическое согласование - наличие общей семы (синтагмемы) в обоих членах сочетания;

2) семантическое несогласование - отсутствие общей семы в одном из членов сочетания;

3) семантическое рассогласование - наличие в пределах синтагмы семантических компонентов, несовместимых с точки зрения реальных предметных отношений [ГАК 1972: 380-384].

По отношению к целям нашего исследования указанные типы могут быть конкретизированы следующим образом:

1) семантика контекста поддерживает значение одушевленности (неодушевленности) имени существительного;

2) семантика контекста не содержит указания на значение одушевленности (неодушевленности) имени существительного;

3) семантика контекста противоречит значению одушевленности (неодушевленности) имени существительного. 
Таким образом, на синтаксическом уровне значение одушевленностинеодушевленности находит выражение в специфике сочетаемости имен существительных с другими языковыми единицами в составе высказывания.

Поскольку возможность употребления субстантивов с нейтральными (по отношению к одушевленности-неодушевленности) словами существует всегда, предметом нашего исследования станет семантическая сочетаемость имен существительных с одушевленно- и неодушевленно-маркированными словами, позволяющая выявить в значениях компонентов сочетаний семы, указывающие на живое и неживое.

В дальнейшем исследование синтагматических связей слов в аспекте одушевленности-неодушевленности будет строиться, в основном, на примере семантического взаимодействия имени существительного и глагола, реализующегося в синтаксических группах субъект - глагол, глагол - объект, так как глаголсказуемое является конструктивным и смысловым центром предложения.

Анализ языкового материала показывает, что семантические особенности имен существительных оказывают существенное влияние на сочетаемость с одушевленно- и неодушевленно-маркированными словами.

Семантическая сочетаемость имен существительных с другими языковыми единицами в аспекте одушевленности-неодушевленности реализуется за счет связующих сем «живое» и «неживое», поэтому наиболее четко выявляются синтагматические свойства субстантивов основных групп, строго противопоставленных по одушевленности - неодушевленности.

По отношению к семантике одушевленности-неодушевленности субстантивов основных групп могут быть описаны две нормативные синтагматические модели:

1. абсолютно одушевленное существительное + одушевленно-маркированный глагол (синтагмема «живое»): отеи простудился; мальчик уснул; пес залаял; лечить отиа; разбудить мальчика; подозвать пса и т.д.;

2. абсолютно неодушевленное существительное + неодушевленно-маркированный (синтагмема «неживое»): вода кипит; чашка разбилась; телевизор сломался; кипятить воду; разбить чашку; чинить телевизор и т.д.

Сочетания, не соответствующие данным моделям, предполагают либо нарушение синтагматической нормы, либо переосмысление значений компонентов, составляющих сочетание.

Многие имена существительные могут сочетаться как с одушевленно-, так и с неодушевленно-маркированными глаголами, что обусловлено семантическими особенностями данных субстантивов: совмещением в их значениях сем, указывающих на живое и указывающих на неживое [НАРУШЕВИч 2002: 4].

Обратимся к более подробному анализу сочетаемости имен существительных выделенных лексико-семантических групп с глаголами, указывающими на одушевленность и неодушевленность.

Имена существительные, обозначающие предметы, осмысливающиеся как живые существа, выступают только в сочетаниях с одушевленно- 
маркированными глаголами. В подобных сочетаниях синтагматическую функцию выполняет сема "живое“": субстантив обозначает живое существо, а глагол - какое-либо действие живого существа или действие, направленное на данное существо. Как правило, оба члена сочетания обладают нейтральным, лишенным образности значением. К существительным регулярно задается вопрос кто? В обычное время люди растут, взрослеют, стареют, подчиняясь ритму годов (И. Эренбург. Буря) - кто взрослеет?, кто стареет?; Нас не встретили. Конвоиры нервничают и перешептываются (Е. Гинзбург. Крутой маршрут.) - кто нервничает?; Гигантские олени вымерли, а их родичи - более мелкие лоси с небольшими рогами выжили (А. Адабашьян. Мировые загадки сегодня) - кто выжил?

Сочетаемость с неодушевленно-маркированными глаголами «абсолютно одушевленным» субстантивам не свойственна.

Существительные, обозначающие предметы, осмысливающиеся как неживые, сочетаются исключительно с неодушевленно-маркированными глаголами. Подобные сочетания реализуются за счет связующей семы «неживое», к именам существительным регулярно задается вопрос что?

Вода зашумела по трубам и полилась... Затем высокое стекло... треснуло червивой трещиной... (М. Булгаков. Собачье сердце) - что полилось?, что треснуло?; Как только дверь несльино затворилась, Павел Петрович быстро размотал шейный платок и стал тихонько раздирать на груди рубашку (Ю. Тынянов. Подпоручик Киже) - что затворилось?; размотал что?;

Имена существительные, обозначающие умерших людей, различаются по своим сочетаемостным свойствам. Субстантиваты усопший, умерший, покойный могут сочетаться с одушевленно-маркированнымиглаголами в форме прошедшего времени благодаря эллипсису определяемого слова со значением лица, повлекшим субстантивацию и изменение семантического наполнения указанных субстантивов: умерший говорил, покойный верил, усопший любил и т.д. В данном случае имена существительные обозначают лиц, ранее живших, однако умерших к настоящему времени. Семантическое согласование с одушевленно-маркированными глаголами осуществляется за счет связующих сем «человек» и «бывший живым». По матери пошел, по Анне Алексевне: Покойница с ума сходила восемь раз (А. Грибоедов. Горе от ума); Может, ты привык, отеи мой, чтобы кто-нибудь почесал тебе на ночь пятки? Покойник мой без этого никак не засыпал (Н. Гоголь. Мертвые души.)

Наличие в значениях названий умерших сем, указывающих на неживое, создает некоторое семантическое противоречие, лежащее в основе сочетаний данных существительных с одушевленно-маркированными глаголами: Члена $M A C$ СОЛИТа Ивана Бездомного. Заявление. Вчера вечером я пришел с покойным Берлиозом на Патриаршие пруды...И сразу поэт запутался, главным образом из-за слова "покойный". С места выходила какая-то безлепица: как это такпришел с покойным? Не ходят покойники !. (М. Булгаков. Мастер и Маргарита).

Слова труп, мертвеи, утопленник и др. сочетаются с одушевленно-маркированными глаголами только в тех случаях, когда являются названиями 
персонажей народных легенд и сказок: Потупив очи в книгу, стал он читать громче свои молитвы и заклятья и сльшал, как труп опять ударил зубами и замахал руками, жселая схватить его (Н. Гоголь. Вий); Долго после этого в деревню стал приходить по ночам беспальй мертвец и тревожил жителей (О шведах. Народная легенда.); Уж с утра погода злится, Ночью буря настает, И утопленник стучится Под окном и у ворот (А.С. Пушкин. Утопленник).

В прямых значениях сочетаемость с одушевленно-маркированными глаголами данным существительным не свойственна.

Сочетаемость с глаголами (разлагаться, разрушаться и др.) осуществляющаяся за счет сем, указывающих на неживое («умерший», «неживой») наиболее характерна для субстантивов труn, мертвец. Так, слово труn, особенно часто употребляющееся в анатомии и криминалистике, может сочетаться со многими неодушевленно-маркированными глаголами: Tpyn ocmblвaеm довольно медленно (С. Рязанцев. Философия смерти); Чем прочнее сделан гроб и чем герметичнее закрыт, тем медленнее разрушается труп (Там же); Герметичность погребения и подземный родникспособствовали тому, чтобы труп окаменел (Там же). Ср. семантический запрет на сочетания типа *”усопший разлагается”, * “покойный разрушается” и т.п.

Изложенные факты указывают на различие в семантике существительных, обозначающих умерших, слова усопиий, покойный, умериий включают сему «человек», в то время как слово труn с ведущей семой «тело умершего» тяготеет к неодушевленным существительным.

Имена существительные, обозначающие человека и животных на стадии эмбрионального развития, сочетаются только с одушевленно-маркированными глаголами, обозначающими физиологические проявления жизни: эмбрион развивается, плод погибает, зародыш питается и т.п. Однако и в указанных сочетаниях, реализующихся за счет связующей семы «формирующийся организм» («формирующееся живое»), наблюдается колебание вопросов в имени существительному (кто?/что?): При внутриутробном заражении эмбрион погибает (А. Казанцев и др. Инфекционные болезни) - кто погибает? и что погибает?; Беременность не прерывается, и плод продолжсает развиваться (Н. Ходаков. Молодым супругам) - кто продолжает развиваться? и что продолжает развиваться?; Особенно страдает зародыш при неполноценном питании женщчины (Там же) - кто страдает и что страдает?

Сочетаемость с неодушевленно-маркированными глаголами существительным данной группы не свойственна.

Таким образом, ограниченная сочетаемость с глаголами, указывающими на одушевленность, а также колебание в постановке вопросов к существительным данной группы отражают колебания в осмыслении соответствующих объектов носителями языка.

Названия микроорганизмов могут сочетаться только с теми одушевленномаркированными глаголами, которые обозначают элементарные проявления жизни: микробы развиваются, вирусы размножаются, бактерии питаются, микроорганизмы погибают и т.п. В подобных сочетаниях связующую функцию 
выполняет сема «живое». Микробы гибнут от слишком высокой или слишком низкой температуры, от ультрафиолетовых лучей солниа (Н. Гальперин. Микробы) - кто гибнет?; Каждый микроб размножается на том месте, где он осел (Там же) - кто размножается?; Многие микробы питаются преимущественно органическими веществами” (Там же) - кто питается?; Бактерии приспособились к существованию в живой ткани (Там же) - кто приспособился?

Если в приведенных выше примерах семантика глагола предполагает постановку вопроса $к m o ?$, то в сочетаниях с нейтральными глаголами вопросы к одному и тому же слову могут быть различными: Наука микробиология изучает различных бактерии и вирусы (Н. Гальперин. Микробы) - изучает кого? и изучает что?; Бактерий относят также и к миру растений(Там же) - что относят ? и кого относят ?; Зимой морозы не уничтожают микробов (Там же) - не уничтожают кого? и не уничтожают что?

Сочетаемость с неодушевленно-маркированными глаголами названиям микроорганизмов не свойственна.

Ограниченная сочетаемость с одушевленно-маркированными глаголами, а также колебание в постановке вопросов свидетельствуют о «размытости» семантики одушевленности-неодушевленности названий микроорганизмов.

Имена существительные, обозначающие животных в качестве пищи, сочетаются только с неодушевленно-маркированными глаголами, при этом связующую функцию выполняют семы «неживое» и «пища». Некоторых животных люди издавна рассматривали преимущественно в качестве продуктов питания (ср. современное слово морепродукты). Например, омары, устрицы, лангусты, как отмечает В.А. Ицкович, «не встречаются в центральной России в живом виде и стали известны сначала как экзотические блюда и лишь позднее - как живые существа». Эти имена существительные, употребляясь с неодушевленно-маркированными словами, обнаруживают два оттенка значения «пища». Для примера сравним два предложения: Волки съели барана За обедом съели барана. В первом случае существительное баран обозначает животное, не подвергшееся кулинарной обработке, в качестве пищи. В данном значении к субстантиву обычно задается вопрос кто?: Все кормятся друг другом. Ястреб убивает и ест перепелку, а перепелка-жука. Лягушка проглатывает насекомых (В. Солоухин. Мед на хлебе) - ест кого?, проглатывает кого?

Второй оттенок значения «пища» связан с обозначением кулинарных блюд, приготовляемых из определенного вида животных. В этом случае к именам существительным регулярно задается вопрос что? Pыбу вымыть, нарезать ломтиками, посолить (Н. Голосова. Питание для здоровья) - посолить что?; Кальмары отварить, нарезать в виде лапши (Там же) - отварить что? Представляю себе твою жену, пытающуюся соорудить в кастрюльке в общей кухне дома пориионные судачки а натюрель! (М. Булгаков. Мастер и Маргарита) - соорудить что?; Так же можно приготовить куропатку, тетерева, фазана (С. Грознов и др. Мясные блюда) - приготовить что?; Когда супруги вернулись в комнату, погорелеи сидел за столом и прямо из железной коробочки ел маринованную рыбу (И. Ильф, Е. Петров. Золотой теленок) - ел что? 
Сочетаемость с одушевленно-маркированными глаголами существительным данной группы не свойственна.

Имена существительные, обозначающие персонажи мифов, легенд, сказок и фантастических произведений. Семантические особенности названий вымышленных существ обусловливают сочетаемость с одушевленно-маркированными глаголами, при этом синтагматическую функцию выполняет сема «представляемое живым». Тут черт засмеялся от радости, вспомнивши, как будет дразнить в аде все хвостатое племя, как будет беситься хромой черт... (Н. Гоголь. Ночь перед Рождеством) - кто засмеялся?; Горе! малый я не сильный, Съест упырь меня совсем. (А. Пушкин. Вурдалак) - кто съест?; Домового ли хоронят, Ведьму ль замужс выдают (А. Пушкин. Бесы) хоронят кого?; На башне спорили химеры - Которая из них урод (О. Мандельштам. "В таверне воровская шайка...”) - спорили кто?; А русалка просыпалась, клянчила то леденщов, то янтарную нитку (А. Толстой. Русалка) - кто просыпался?, кто клянчил?;

Некоторые существительные данной группы могут сочетаться с неодушевленно-маркированным иглаголами, обозначающими специфические признаки, приписываемые отдельным вымышленным существам: Выпучился водяной, лопнул и побежсал ручьем быстрым в озеро (А. Толстой. Иван да Марья)

Таким образом, сочетаемость преимущественно с одушевленно-маркированными глаголами указывает на преобладание в значениях имен существительных данной группы сем, указывающих на живое.

Имена существительные, являющиеся названиями кукол, достаточно часто выступают в сочетаниях с одушевленно-маркированными глаголами, что подтверждает положение о наличии в значениях данных субстантивов семы «функциональное подобие животного». Подобные сочетания, усиливающие семантику одушевленности и обусловливающие постановку вопроса $\kappa m o$ ?, особенно часто встречаются в речи детей, а также при описании детских игр с куклами: Перед сном ты опять играла у меня в кабинете. Кормила кукол (Л. Пантелеев. Наша Маша) - кормила кого? Девочки пяти и шести лет везли нарядную кукольную коляску, в которой спала большая и нарядная немецкая кукла (Там же) - кто спал?; Бежит в столовую и видит... на чашке весов сидит Машкина кукла Леля (Там же) - кто сидит?; Обогащенная вчерашним опытом, сегодня с утра играет в кукль: пеленает свою крохотную тятяшечку (Там же) - пеленает кого?

В то же время существительным кукла, матрешка, неваляшка и др. свойственна сочетаемость с неодушевленно-маркированными глаголами. В этих сочетаниях связующую функцию выполняет сема «неживое», а к именам существительным задается вопрос что?: матрешка треснула - что треснуло?; кукла сломалась - что сломалось?; завести куклу (ключом) - что завести? и т.п. Ты заешь, какая у меня беда случилась? Чиполино у меня сломался (Л. Пантелеев. Наша Маша) - что сломалось?; На наших глазах кукла разбилась на мелкие кусочки (С. Серов. Игрушка) - что разбилось?; Не раз чинил ее кукол (Л. Пантелеев. Наша Маша) - что чинил? 
Андрей НАРУШЕВИЧ

Таким образом, наличие в значениях слов, обозначающих кукол, компонентов «неживое» и «подобие живого» позволяет этим лексемам вступать в сочетания как с одушевленно-, так и с неодушевленно-маркированными глаголами, причем сочетание с глаголами разных групп возможно даже в пределах узкого контекста: Это заводная кукла Анабелла. Я завожу ее гдето на спине...и кукла начинает ходить...Поворачиваю другой рычажок...и кукла начинает танцевать и петь (Л. Пантелеев. Наша Маша) - завожу что?, кто начинает танцевать?

Имена существительные, являющиеся названиями игровых фигур, могут вступать в сочетания с одушевленно-маркированными глаголами благодаря семе «функциональное подобие живого», выполняющей синтагматическую функцию в подобных сочетаниях Куда бы ни отступил черный ферзь, ладья в углу погибла (Из периодики) - кто отступил?, кто погиб?; Kp-d4 и король догоняет черную пешку (Из периодики); Две черные фигуры принесли себя в жертву (Из периодики); Белопольный слон белых никак не мог со своего первоначального поля $f 1$ добраться до а8 (Из периодики) - кто не мог добраться?; Жертва ладьи отвлекла коня и позволила перекрыть важный пункт (Из периодики) - отвлекла кого? Белье спасают коня и выравнивают шансы (Из периодики) - спасают кого? В приведенных сочетаниях постановка вопроса кто? обусловлена влиянием одушевленно-маркированных глаголов, активизирующих семантику одушевленности субстантивов.

Сочетаемость с неодушевленно-маркированными глаголами свидетельствует о наличии в значении названий игровых фигур семы «неживое»; ферзь сломался; слон треснул; ладья разбилась; валет порвался; туз измялся и т.д.

Совмещение сем «неживое» и «функциональное подобие живого» обусловливает сочетаемость названий игровых фигур как с одушевленно-, так и с неодушевленно-маркированными глаголами.

Имена существительные, обозначающие совокупности живых существ. Общая сема «совокупность» создает условия для сочетаемости имен существительных данной группы с неодушевленно-маркированными глаголами: разделить отряд - разделить что?; расформировать полк - расформировать что?; уменьиить стадо - уменьшить что?; стая разделилась - что разделилось? и т.д.

Отряд ловко дробился, через каждые десять, двадиать шагов от него отскакивал верховой... (М.Горький. Жизнь Клима Самгина.); Толnа... покачнулась назад и стала рассыпаться на кучки, на единищьл (Там же) - стало рассыпаться что?

Сема «люди» (или сема «животные») выполняет связующую функцию в сочетаниях с одушевленно-маркированными глаголами, обозначающими действия множества живых существ: народ сбежался - кто сбежался?; толпа расходилась - кто расходился?; стадо разбежалось - кто разбежался? и т.д.

Имена существительные рассматриваемой группы могут употребляться в речи с одушевленно-маркированными глаголами за счет метонимического значения, активизирующего сему «живое»: Смешанные, все увеличиваюшиеся толпы бежали назад, к тому месту, где пять минут назад войска проходили мимо императоров (Л. Толстой. Война и мир) - кто бежал?; кто проходил?; 
Заворчала, зашумела, закричала толпа, ревя, кинулась к мосту (А. Толстой. Петр Первый) - кто закричал?; кто кинулся?; Полки потребовали жалованныле грамоты (Там же) - кто потребовал?

Употребление имен существительных, обозначающих растения, с одушевленно-маркированными глаголами ограничено. Как правило, эти существительные сочетаются с глаголами, обозначающими наиболее общие проявления жизни (развиваться, расти, размножаться и т.п.), а также с глаголами, обозначающими проявления жизнедеятельности, присущие только растительным организмам (цвести, прорастать, плодоносить). Характерно то, что в любых сочетаниях к существительным данной группы регулярно задается вопрос что?

Он держал курс на островок, где росли две низкие, исковерканные сыростью сосенки (Б. Васильев. А зори здесь тихие) - что росло?; Папоротник размножается при помощи спор (П. Генгель. Мир растений) - что размножается?; Размеры растения увеличиваются, оно растет и развивается. (А. Цингер. Занимательная ботаника) - что развивается?

Перечень глаголов, указывающих на неодушевленность (неодушевленномаркированных), с которыми могут сочетаться названия растений достаточно обширен: корчевать (пилить, рубить, жечь, ломать и т.д.) деревья; рвать, срезать, цветы; дерево трескается (горит, ломается, сохнет и т.д.).

Косили траву с удовольствием, работали до изнеможения (В. Распутин. Прощание с Матерой) - косили что?; Известны случаи, когда бобры срезали вербы диаметром больше метра (В. Туров. Бобры в Молдавии) - срезали что?; Степь становится неприглядной. Почти все растения засыхают (А. Кожевников. По тундрам, лесам, степям и пустыням) - что засыхает?

Сочетаемость преимущественно с неодушевленно-маркированными глаголами, а также постановка вопроса что? свидетельствуют о наличии семы «неживое» в семантике субстантивов, обозначающих растения.

\section{Заключение}

Таким образом, анализ сочетаемости имен существительных выделенных лексико-семантических групп с одушевленно- и неодушевленно-маркированными глаголами позволяет выявить семантические особенности имен существительных в аспекте одушевленности-неодушевленности.

Способность субстантивов промежуточных групп выступать в сочетаниях как с одушевленно-, так и с неодушевленно-маркированными глаголами подтверждает положение о совмещении в их семантике сем, указывающих на живое и неживое.

Исследование семантического взаимодействия имен существительных и сочетающихся с ними одушевленно- и неодушевленно-маркированных глаголов обнаруживает следующие закономерности:

1) «абсолютно-одушевленные» субстантивы сочетаются преимущественно с одушевленно-маркированными глаголами, что усиливает значение одушевленности имени существительного; 
2) «абсолютно-неодушевленные» субстантивы сочетаются преимущественно с неодушевленно-маркированными глаголами, что способствует усилению значения неодушевленности;

3) имена существительные промежуточных групп могут употребляться как с одушевленно-, так и с неодушевленно-маркированными глаголами, что подтверждает положение о совмещении в значениях этих субстантивов сем, указывающих на живое и неживое.

Исследование категории одушевленности-неодушевленности позволяет поставить вопрос о гносеогенном факторе формирования значений и о специфике выражения в языке особенностей познавательного опыта освоения человеком окружающего мира.

\section{Литература}

ГАК 1972: Гак, В.Г. К проблеме семантической синтагматики // Проблемы структурной лингвистики 1971. Москва: Наука.

КозІнА 2012: Козіна, Ю В. Історія категорії істот/неістот в українській мові: автореф. дис ... канд. філол. наук: 10.02.01. Запоріжжя: Б.в.

КРысьКО 1994: Крысько, В. Б. Развитие категории одушевленности в истории русского языка. - Москва: Lyceum.

КузьменКОВА 1980: Кузьменкова, Т.В. Категория одушевленности-неодушевленности в современном белорусском языке: диссертация ... кандидата филологических наук: 10.02.02. - Минск.

МАДОян 1980: Мадоян В.В. Категория одушевленности имен существительных в древнерусском языке (на материале памятников северо-западной Руси XIII-XIV вв.): дис. ... канд. филол. наук: 10.02.01 / Мадоян В.В. -Москва.

МорОз 2007: Мороз Т. Ю. Хитання в граматичному оформленні істотовості / неістотовості деяких іменників як результат невизначеності буттєвого модусу реалій, що ними позначаються / Т.Ю. Мороз // Вісник Луганського національного педагогічного університету імені Тараса Шевченка: Філологічні науки. - Луганськ : Альмаматер, 2007. №11 (128): 54 -64 .

НАРУШЕВич 2002: Нарушевич, А.Г. Категория одушевленности-неодушевленности и языковая картина мира // Русский язык в школе. 2002. № 3: 24-26.

СтЕПАНОВ 1981 Степанов, Ю.С. Имена, предикаты, предложения. (Семиологическая грамматика). Москва: Наука.

ШАКАР 2018: Шакар, Р. Семантическая категория одушевлённости и её выражение в русском словообразовании. Казань: Издательство «Бук».

Андрей НАРУШЕВИЧ

Таганрогский институт имени А.П. Чехова (филиал Ростовского государственного экономического университета)

Таганрог, Россия anarushevich@yandex.ru

ORCID ID: 0000-0003-0597-3031 